\title{
New challenges and opportunities for industrial biotechnology
}

\author{
Guo-Qiang Chen ${ }^{1,2^{*}}$
}

\begin{abstract}
Industrial biotechnology has not developed as fast as expected due to some challenges including the emergences of alternative energy sources, especially shale gas, natural gas hydrate (or gas hydrate) and sand oil et al. The weaknesses of microbial or enzymatic processes compared with the chemical processing also make industrial biotech products less competitive with the chemical ones. However, many opportunities are still there if industrial biotech processes can be as similar as the chemical ones. Taking advantages of the molecular biology and synthetic biology methods as well as changing process patterns, we can develop bioprocesses as competitive as chemical ones, these including the minimized cells, open and continuous fermentation processes et al.
\end{abstract}

Keywords: Industrial biotechnology, Shale gas, Oil fields, PHB, Bioplastics, Biofuels, Bulk chemicals

The commercialization of industrial biotechnology is not as fast as we expected. Originally, we believe that production of bulk chemicals including biofuels, polymeric materials and chemical agents using microorganisms or enzymes will provide low cost, environmentally friendly products to partially replace petro-chemicals products [1]. However, this looks not so easy to materialize due to the facts that:

1. Petroleum does not rise in price too much after 2008 financial crisis, other alternative energy sources, especially shale gas, natural gas hydrate (or gas hydrate) and sand oil, have been discovered in large amount and their exploitations are increasingly moving toward a very competitive price;

2. The exhaustion of petroleum seems to be a remote reality

3. Agriculture raw materials for bioprocessing are becoming increasingly costly

4. Low cost raw material cellulose can not be easily used for microbial processes at least for the next $5-10$ years

Correspondence: chengq@mail.tsinghua.edu.cn

${ }^{1}$ MOE Key Lab of Bioinformatics and Systems Biology, Department of Biological Science and Biotechnology, School of Life Sciences, TsinghuaPeking Center for Life Sciences, Tsinghua University, Beijing 100084, China ${ }^{2}$ Center for Nano and Micro Mechanics, Tsinghua University, Beijing 100084, China

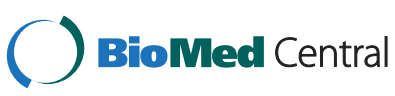

(C) 2012 Chen; licensee BioMed Central Ltd. This is an Open Access article distributed under the terms of the Creative Commons Attribution License (http://creativecommons.org/licenses/by/2.0), which permits unrestricted use, distribution, and reproduction in any medium, provided the original work is properly cited.
5. Bioprocessing is still not as effective as chemical processing, resulting in high cost of bio-products (Table 1)

6. Bioprocessing that requires large amount of fresh water has had increasing concerns in many water shortage areas

7. The chemical industry is also evolving competitive in various ways including environmentally friendliness, the use of renewable resources (biomass) for making chemicals that are normally derived from petrochemicals

8. The rapid development of $\mathrm{C} 1$ chemical engineering products

9. Large amount of funding is not more directed to industrial biotechnology.

Taking the example of polyhydroxyalkanoates (PHA), a biopolyester family that has been exploited to become an industrial value chain [2-4], PHA has not been able to commercially produce in large scale due to the difficulty to lower the production cost especially for their applications as bioplastics that are considered as biodegradable and bio-based despite the possibility of using $\mathrm{CO}_{2}$ as substrate [5].

To successfully commercialize PHA, we must keep working hard on the "high volume and low price" strategy by developing better PHA production strains and cost competitive processes. While for some special 
Table 1 Comparison of industrial biotechnology and chemical technology

\begin{tabular}{lll}
\hline \multicolumn{1}{c}{ Items } & \multicolumn{1}{c}{ Industrial biotechnology } & Chemical technology \\
\hline Reaction Time & Slow: production takes days & Fast: production takes hours \\
Substrates & Agricultural products & Petroleum or its derivatives \\
Conversion of substrates to products & Low: e.g. PHB/glucose $\approx 33 \mathrm{wt} \% \mathrm{PHA} /$ fatty acids $\approx 60 \mathrm{wt} \%$ & High: e.g. Polyethylene/ethylene $\approx 100 \%$ \\
Medium & Water & Mostly organic solvents \\
Consumption of water & A lot & Less \\
Reaction conditions & $30-40^{\circ} \mathrm{C}$, normal pressure & Generally $>100^{\circ} \mathrm{C}$, High Pressures \\
Product concentration & Low: Several mg to $100 \mathrm{~g} / \mathrm{L}$ & Very high \\
Product recovery cost & Very high & Low to medium \\
Processing & Normally discontinuous one & Can be continuous \\
Sterilization & Necessary & No need \\
Production facility cost & Very high & Low to high (explosive proof) \\
Waste water & Not toxic, easier to treat & Generally toxic, difficult to treat \\
\hline
\end{tabular}

applications, "low volumes and high price" can be applied, such as products to be used for biomedical purposes, specialty polymers [6,7], chiral monomers, drug development and special applications et al. [8,9]. And this is generally true in order to survive this competitive environment for industrial biotechnology, it must be competitive with the chemical industry. Let's see what we can do to make this happen. In addition, it is also important to be able to develop processes that combined the advantages of chemical industry to supplement the weaknesses of industrial biotechnology (Table 1).

The newly emerging synthetic biology approaches may offer some clues for developing competitive technology for industrial biotechnology to produce "high volume and low price" products (Table 2). At the same time, bio-processing should try to become as similar as the chemical industry, including the need to develop continuous and open fermentation processes for e.g. making biofuels and PHA bioplastics [10-12]. Also, from now and toward a distant future, foods are still important for feeding the world population, the development of bioprocesses based on kitchen waste or activated sludge as substrates may also be an important option for a competitive industrial biotechnology (Table 2).

Combination of bio- and chemical processes can offer a lot of advantages including bio-based $\left(\mathrm{CO}_{2}\right.$ reduction) and fast reaction. Typical example includes the bioproduction of lactic acid from anaerobic fermentation

Table 2 Problems to be solved for making industrial biotechnology competitive to chemical technology

\begin{tabular}{|c|c|c|}
\hline Problems & Weakness of Industrial biotechnology & Possible solutions \\
\hline Microorganisms grow too slow & Slow: production takes days & Minimizing the microbial cells \\
\hline Microbes can not use mixed substrates & $\begin{array}{l}\text { Agricultural products are mostly mixed } \\
\text { substrates }\end{array}$ & $\begin{array}{l}\text { Assembling pathways that can metabolize } \\
\text { mixed substrates }\end{array}$ \\
\hline Low conversion of substrates to products & $\begin{array}{l}\text { Cell metabolism turn substrates into } \\
\mathrm{CO}_{2}, \mathrm{H}_{2} \mathrm{O} \& \text { byproducts }\end{array}$ & $\begin{array}{l}\text { Removing unnecessary pathways consuming } \\
\text { substrates }\end{array}$ \\
\hline High Consumption on fresh $\mathrm{H}_{2} \mathrm{O}$ & Fresh $\mathrm{H}_{2} \mathrm{O}$ as medium et al. & Utilization of sea water for cell growth \\
\hline Microbial cells grow to very low density & $\begin{array}{l}\text { Product concentration low: Several } \\
\text { mg to } 100 \mathrm{~g} / \mathrm{L}\end{array}$ & $\begin{array}{l}\text { Minimizing oxygen demand for aerobic cells \& } \\
\text { reducing Quorum sensing effects }\end{array}$ \\
\hline Discontinuous processing & Contamination concerns & Developing continuous process \\
\hline Sterilization costs high & High pressed steam & $\begin{array}{l}\text { Contamination resisting strains grown in } \\
\text { open systems }\end{array}$ \\
\hline High energy demand for intensive aeration & $\begin{array}{l}\text { Aerobic microorganisms need a lot of } \\
\text { oxygen for growth }\end{array}$ & Developing anaerobic bioprocesses \\
\hline Difficulty to control the bio-processes & Complicated cellular metabolisms & $\begin{array}{l}\text { Artificial cells that contain only necessary } \\
\text { metabolic pathways }\end{array}$ \\
\hline One product by one microbial organism & Different organism has different strength. & $\begin{array}{l}\text { Development of a platform organism for } \\
\text { many products }\end{array}$ \\
\hline Organisms consume food related products & Food for Fuels (Chemicals) & Kitchen wastes or activated sludge as substrates \\
\hline Production facility costly & Costly materials and sensors & The use of carbon steel facilities et al. \\
\hline
\end{tabular}


that is very effective and has only one single lactic acid product, and chemical polymerization of lactide to polylactide (PLA), a biodegradable green plastic $[2,13]$. The PLA story is a successful combination of bio- and chemical advantages. Others like succinic acid and 1,4-butanol bio-production and their copolymerization are under intensive $R \& D[2,13]$. However, at the end, commercial successes have to be dependent on economy.

\section{Competing interests}

The author declares that he has no competing interests.

\section{Acknowledgements}

The author of this article is supported by grants from the State Basic Science Foundation 973 (Grant No. 2012CB725201) and State Industrialization Project (Grant No. 2012BAD32B02).

Received: 13 August 2012 Accepted: 14 August 2012

Published: 20 August 2012

\section{References}

1. Chen $\mathrm{GQ}$, Kazlauskas R: Chemical biotechnology in progress. Curr Opin Biotechnol 2011, 22:1-2.

2. Chen GQ, Patel M: Plastics derived from biological sources: Present and future - A technical and an environmental review. Chemical Rev 2012. 112:2082-2099.

3. Chen GQ: A Polyhydroxyalkanoates Based Bio- and Materials Industry. Chem Soc Rev 2009, 38:2434-2446.

4. Gao X, Chen JC, Wu Q, Chen GQ: Polyhydroxyalkanoates as a source of chemicals, polymers and biofuels. Curr Opin Biotechnol 2011, 22:1-7.

5. Hemple F, Bozarth AS, Lindenkamp N, Klingl A, Zauner S, Linne U, Steinbuchel A, Maier UG: Microalgae as bioreactor for bioplastic production. Microb Cell Fact 2011, 10:81.

6. Tripathi $L$, Wu LP, Chen GQ: Microbial synthesis of diblock copolymer poly-3-hydroxybutyrate-block-poly-3-Hydroxyhexanoate [P(3HB)-b-P $(3 \mathrm{HHx})]$ by a genome reduced Pseudomonas putida KT2442. Microb Cell Fact 2012, 11:44

7. Zhou XY, Yuan XX, Shi ZY, Meng DC, Jiang WJ, Wu LP, Wu Q, Chen JC, Chen GQ: Hyperproduction of poly(4-hydroxybutyrate) from glucose by recombinant E. coli. Microb Cell Fact 2012, 11:54.

8. Zhang S, Wang ZH, Chen GQ: Microbial polyhydroxyalkanote synthesis repression protein PhaR as an affinity tag for recombinant protein purification. Microb Cell Fact 2010, 9:28.

9. Wang ZH, Ma P, Chen J, Zhang J, Yao YC, Zhang HF, Chen GQ: A heterogeneous two-hybrid system in Escherichia coli based on polyhydroxyalkanoates synthesis regulatory proteins PhaR. Microb Cell Fact 2011, 10:21

10. Zhang XJ, Luo RC, Wang Z, Deng Y, Chen GQ: Applications of (R)-3-hydroxyalkanoate Methyl Esters Derived from Microbial Polyhydroxyalkanoates as Novel Biofuel. Biomacromolecules 2009, 10:707-711.

11. Tan D, Xue YS, Gulsimay, Chen GQ: Unsterile and Continuous Production of Polyhydroxybutyrate by Halomonas TD01. Bioresource Technol 2011, 102:8130-8136.

12. Johnson K, Jiang Y, Kleerebezem R, Muyzer G, van Loosdrecht MCM: Enrichment of a Mixed Bacterial Culture with a High Polyhydroxyalkanoate Storage Capacity. Biomacromolecules 2009, 10:670-676.

13. Lee JW, Kim HU, Choi S, Yi J, Lee SY: Microbial production of building block chemicals and polymers. Curr Opin Biotechnol 2011, 22:758-767.

\section{Submit your next manuscript to BioMed Central and take full advantage of:}

- Convenient online submission

- Thorough peer review

- No space constraints or color figure charges

- Immediate publication on acceptance

- Inclusion in PubMed, CAS, Scopus and Google Scholar

- Research which is freely available for redistribution 